\title{
Peningkatan Kesejahteraan Ekonomi Masyarakat Pesisir Melalui Pemberdayaan Perempuan
}

\author{
Donna NP Butarbutar ${ }^{1,2}$, Lelo Sintani ${ }^{3}$, Luluk Tri Harinie ${ }^{3}$ \\ ${ }^{1}$ Dinas Kelautan dan Perikanan Provinsi Kalimantan Tengah, J. Brigjend Katamso No. 2 Palangka Raya, Indonesia 73112 \\ ${ }^{2}$ Alumni Program Studi Magister Manajemen Universitas Palangka Raya \\ ${ }^{3}$ Program Studi Magister Manajemen Universitas Palangka Raya \\ * Korespondensi: Donna NP Butarbutar (Email: donna zhunlie@yahoo.co.id)
}

Diterima: 18 Oktober 2019

Direvisi: 13 Januari 2020

Disetujui: 20 Januari 2020

\begin{abstract}
This study examines the strategy of community economic welfare improvement through empowering coastal women in utilizing fishery waste products. The informants were purposively pick up from those who attended the training of waste processing of fishery products and took the follow-up training. Additional data were collected through observation, interview and documental study. The cumulative data were then examined used SWOT analysis. The results show that the workable strategy was SO (Strengths-Opportunities) strategy, namely using internal strengths to get the advantage from external opportunities. The weaknesses needs for improvement were lack of skill, lack of tools or equipment to process the products, lack of funds, unregistered business body and limited market. Meanwhile, the threats from competitors of similar products, unavailability of product distributors, consumer demand for more creative products, and rapid technological development are hard to follow by coastal women.
\end{abstract}

\section{Keywords}

KUBE, strategy, community empowerment, cattle

\section{PENDAhUluAN}

Masyarakat pesisir umumnya kepala keluarga memiliki pekerjaan sebagai nelayan penangkap ikan di laut, sedangkan para istri bekerja sebagai ibu rumah tangga. Masyarakat pesisir memiliki kondisi ekonomi yang relatif rendah (Hilyana et al., 2019). Sebagian besar (63,47\%) penduduk miskin di Indonesia berada di daerah pesisir dan pedesaan. Hal ini perlu menjadi perhatian mengingat ada keterkaitan erat antara kemiskinan dan pengelolaan wilayah pesisir (Menggala, 2016).

Potensi sektor kelautan yang besar seharusnya mampu memberi kontribusi terhadap peningkatan kesejahteraan masyarakat khususnya masyarakat nelayan dan dapat meningkatkan pembangunan yang merata. Pembangunaan dan pemanfaatan di sektor pengelolaan sumber daya kelautan dan perikanan masih belum mampu meningkatkan kesejahteraan masyarakat pesisir. Keadaan seperti ini menempatkan masyarakat pesisir saat ini masih merupakan masyarakat miskin baik secara kultural maupun struktural, keadaan seperti ini semakin membuat kerentanan kemiskinan (Duradin, 2017).

Provinsi Kalimantan Tengah memiliki 7 (tujuh) kabupaten pesisir dengan panjang garis pantai 750,6 km
(Badan Pusat Statistik, 2000). Dengan adanya tujuh kabupaten pesisir ini, jumlah rumah tangga perikanan (RTP) pada perairan laut sebanyak 7.624 RTP. Pada daerah pesisir ini laki-laki sebagai kepala rumah tangga lebih berperan sebagai nelayan penangkap ikan di laut untuk mata pencaharian, sedangkan perempuan (istri) sebagian besar berperan sebagai ibu rumah tangga.

Kepala keluarga yang bekerja sebagai nelayan memiliki pendapatan yang tidak pasti dan ini mendorong kelompok ibu rumah tangga nelayan untuk bekerja memenuhi kebutuhan hidup rumah tangga (Karina et al., 2018). Peran perempuan dalam pemasaran hasil tangkapan tidak memberikan kontribusi pendapatan secara langsung dalam nafkah rumah tangga. Mereka hanya berperan membantu memasarkan hasil tangkapan dan tidak mengambil keuntungan dari kegiatan tersebut, seluruh hasil penjualan diserahkan pada istri pemilik perahu untuk kemudian dibagi sesuai dengan peran masing-masing dalam penangkapan ikan. Pemilik perahu mendapatkan bagian sebanyak $60 \%$ sedangkan sisanya dibagi rata kepada seluruh awak perahu (Widodo et al., 2011).

Pada usaha pengolahan hasil perikanan, para 
perempuan pesisir juga berperan pada keseluruhan proses pengolahan ikan dan pemasarannya. Perempuan pesisir memiliki posisi strategis dalam setiap tahapan kegiatan usaha perikanan dan menjadikan perempuan sebagai salah satu titik tumpu dalam program pembangunan perekonomian masyarakat. Hal ini menunjukkan keterlibatan perempuan pesisir dalam usaha perikanan perlu menjadi perhatian untuk setiap program pemberdayaan di masyarakat pesisir (Nurlaili dan Muhartono, 2019).

Demikian pula hal nya dengan peran perempuan di Desa Ujung Pandaran tidak berbeda jauh dengan peran perempuan di daerah pesisir lainnya. Perempuan desa Ujung Pandaran berprofesi utama sebagai ibu rumah tangga dengan keahlian lain sebagai pedagang hasil perikanan/tangkapan. Selain itu, sebagian besar sambil menunggu suami pulang dari melaut mereka melakukan pengolahan ikan hasil tangkapan yang bernilai jual rendah seperti membuat dan menjemur ikan asin ataupun mengupas udang, sehingga dapat dikatakan perempuan nelayan desa Ujung Pandaran mempunyai waktu luang yang banyak.

Perempuan pesisir yang juga merupakan istri nelayan berkewajiban membantu suami mereka dan sebagai ibu rumah tangga, kaum perempuan ikut bertanggung jawab meningkatkan kesejahteraan rumah tangganya. Peran demikian disadari sepenuhnya oleh istri nelayan karena hasil tangkapan suami dari kegiatan melaut bersifat tidak pasti dari aspek perolehan dan tingkat pendapatan. Saat ini bnyak sekali perempuan yang telah bekerja untuk berkontribusi terhadap pemenuhan perekonomian keluarga (Heriyanto, 2017).

Mengacu pada peraturan Pemerintah dalam Inpres tersebut Nomor 9 Tahun 2000 tentang PUG dalam Pembangunan Nasional, mengamanatkan bahwa semua Kementerian dan Lembaga Pemerintah baik di tingkat pusat maupun daerah untuk mengintegrasikan pengarusutamaan gender dalam tahapan proses pembangunan mulai dari perencanaan, penyusunan, pelaksanaan, pemantauan dan evaluasi pada seluruh bidang pembangunan. Secara spesifik juga diamanahkan dalam Permendagri Nomor 15 tahun 2008 tentang Pedoman Pelaksanaan Pengarusutamaan di Daerah. (Handajani et al., 2016). Kementerian Kelautan dan Perikanan dituntut untuk meningkatkan ekonomi masyarakat pesisir, oleh karenanya Dinas Kelautan dan Perikanan Provinsi Kalimantan Tengah melaksanakan kegiatan Pelatihan Akses Permodalan Masyarakat Pesisir melalui program pengelolaan sumberdaya kelautan dan pesisir. Kegiatan Pelatihan tersebut dirasa mampu dalam mewujudkan pencapaian target yang ditentukan serta pelaksanaan kegiatan melibatkan peran perempuan dan laki-laki, dimana partisipasi perempuan akan lebih dominan.

Kegiatan pemberdayaan perempuan pesisir di Desa Ujung Pandaran Kabupaten Kotawaringin Timur, yang telah dilakukan adalah pemanfaatan limbah hasil perikanan yang difokuskan pada cangkang kerang menjadi kerajinan yang bernilai jual dan memiliki nilai ekonomis yang tinggi. Limbah hasil perikanan di pesisir Ujung Pandaran begitu banyak dan terbengkalai begitu saja, sehingga secara visual pun sangat mengganggu. Limbah tersebut dari segi ekonomi dapat dipergunakan dan diolah menjadi barang yang bernilai jual tinggi sehingga dapat membantu ekonomi masyarakat pesisir dan sekitarnya.

Di desa Ujung Pandaran, perempuan pesisir secara perorangan sebagian besar sudah memanfaatkan limbah hasil perikanan menjadi sebuah produk kerajinan. Akan tetapi kendala yang dihadapi dalam Pengembangan usaha produk kerajinan limbah hasil perikanan tersebut yaitu masalah modal dan kesulitan dalam pemasaran. Oleh karena itu, peran pemerintah sangat diharapkan dalam memfasilitasi perempuan pesisir pengrajin limbah hasil perikanan untuk mendapatkan tambahan modal maupun memperluas pemasaran. Walaupun demikian, dari segi pemasaran para perempuan pesisir pengrajin limbah hasil perikanan diharapkan mampu menciptakan jejaring dan memanfaatkan perkembangan sosial media dan memperluas jangkauan pemasaran produknya. Selain itu, perempuan pesisir pengrajin limbah hasil perikanan haruslah mampu semakin kreatif dan inovatif dalam menciptakan produk yang ekonomis dan bernilai jual tinggi. Perempuan pesisir pengrajin limbah hasil perikanan memiliki peran yang besar dalam menentukan strategi-strategi apa saja yang harus diambil, diterapkan, dan mungkin juga apa yang perlu dihilangkan untuk pengembangan usaha kerajinan yang dijalankan.

Dalam menjalankan usaha kerajinan limbah hasil perikanan sampai saat ini perempuan pesisir masih belum memiliki strategi yang terukur sehingga dirasa perlu melakukan penelitian untuk merumuskan suatu strategi yang tepat agar perempuan pesisir pengrajin limbah hasil perikanan yang melakukan usaha kerajinan ini dapat mengembangkan usahanya dengan lebih baik lagi, terutama untuk mengatasi berbagai ancaman dan merebut peluang yang ada. Hal ini sejalan dengan pendapat Rangkuti (2018) yang menyatakan bahwa suatu kelompok dapat mengembangkan strategi untuk mengatasi ancaman eksternal dan merebut peluang yang ada. Proses analisis, perumusan dan evaluasi strategistrategi itu disebut perencanaan strategis. Tujuan utama perencanaan strategis adalah agar kelompok dapat melihat secara objektif kondisi-kondisi internal dan eksternal, sehingga perusahaan dapat mengantisipasi perubahan lingkungan eksternal.

Beberapa penelitian terdahulu yang berkaitan dengan peran perempuan pesisir maupun tentang pemberdayaan perempuan pesisir seperti di Sri lanka (Koralagama et al., 2017) dan Indonesia (Putri, 2019; Rahim, 2018; Rostiyati, 2018; Imaniar, 2017; Widodo, 2011)

Penelitian ini bertujuan untuk mengidentifikasi faktor -faktor internal dan eksternal pada perempuan pesisir 
pengrajin limbah hasil perikanan agar dapat merumuskan strategi yang tepat untuk mencapai tujuannya dalam pengembangan kerajinan limbah hasil perikanan.

Beberapa penelitian tentang pemberdayaan masyarakat miskin telah banyak dilakukan. Namun demikian penelitian yang dilakukan ini tidak akan terlepas dan mungkin saja mengacu kepada sumbersumber dan literatur-literatur yang sama atau hampir sama dengan penelitian sebelumnya, sehingga penelitian yang dilakukan ini diharapkan dapat lebih melengkapi.

\section{METODOLOGI}

\subsection{Rancangan Penelitian}

Penelitian ini diidentifikasi melalui pendekatan kualitatif dalam menangkap deskripsi umum peningkatan kesejahteraan ekonomi masyarakat pesisir melalui pemberdayaan perempuan pesisir pengrajin limbah hasil perikanan di desa Ujung Pandaran Kabupaten Kotawaringin Timur. SWOT digunakan untuk identifikasi posisi strategis melalui pendekatan materiks. Rekomendasi kebijakan dianalisis dengan pendekatan kualitatif untuk menganalisis peningkatan kesejahteraan masyarakat pesisir melalui pemberdayaan perempuan.

Data lapangan yang sifatnya aktual dan kontekstual diperlukan untuk mengkaji penelitian ini melalui pendekatan kualitatif. Selain itu, dengan menggunakan metode deskriptif kualitatif maka memungkinkan peneliti untuk dapat menyesuaikan diri dengan situasi yang berubah-ubah dalam penelitian ini. Peneliti menggambarkan fenomena-fenomena yang diteliti dan kemudian menguraikannya dalam bentuk narasi yang menunjukkan bahwa faktor-faktor internal (kekuatan dan kelemahan) maupun faktor-faktor eksternal (peluang dan ancaman) dapat menentukan strategi dalam meningkatkan kesejahteraan ekonomi masyarakat pesisir melalui pemberdayaan perempuan.

\subsection{Prosedur Pengumpulan Data}

Data dikumpulkan dari informan dengan menggunakan metode purposive sampling. Teknik penarikan purposive sampling digunakan dengan menentukan kriteria khusus terhadap sampel, terutama orang-orang yang dianggap ahli atau memiliki kewenangan yang tinggi (Sugiyono, 2010). Informan dalam penelitian ini adalah perempuan pesisir yang telah mengikuti pelatihan dan menindaklanjutinya dengan melakukan kerajinan limbah hasil perikanan

Data dikumpulkan dengan metode observasi, wawancara, dan studi dokumen. Prosedur ini dianggap tepat dilakukan pada penelitian kualitatif untuk mengumpulkan data-data yang mendukung hasil atau temuan penelitian dengan menggunakan wawancara secara mendalam yang kemudian dibandingkan dengan hasil observasi dan studi dokumen (Ropiah et al., 2018).

\subsection{Analisis Data}

Data dianalisis menggunakan SWOT, yaitu analisis kekuatan, kelemahan, peluang, dan ancaman (Strengths, Weakness, Opportunities, and Threats). Menurut Rangkuti (2018), SWOT merupakan alat bantu analisis untuk mengidentifikasi berbagai faktor secara sistematis dengan melihat hubungan atau interaksi antara faktorfaktor internal berupa kekuatan dan kelemahan terhadap faktor-faktor eksternal berupa peluang dan ancaman sehingga dapat merumuskan suatu strategi bagi perusahaan atau organisasi.

Hasil analisis lingkungan internal dan eksternal akan diterjemahkan ke dalam faktor keunggulan dan kekurangan internal (kekuatan dan kelemahan) serta faktor keunggulan dan kekurangan eksternal (peluang dan ancaman) yang terdapat dalam analisa SWOT. Kondisi sistem ini dikelompokkan oleh Rangkuti (2018) ke dalam empat kuadran.

Kuadran 1: merupakan situasi yang sangat menguntung kan karena didukung oleh adanya kekuatan dan peluang sehingga dapat memanfaatkan peluang yang ada. Strategi yang dilakukan adalah mendukung kebijakan pertumbuhan yang agresif (growth oriented strategy).

Kuadran 2: merupakan situasi dimana adanya ancaman diimbangi oleh adanya kekuatan internal sehingga strategi yang diterapkan adalah strategi diversifikasi (produk/pasar) dengan menggunakan kekuatan untuk memanfaatkan peluang jangka panjang.

Kuadran 3: merupakan situasi ketika peluang pasar sangat besar namun perusahaan memiliki kendala/kelemahan internal yang juga besar sehingga strategi difokuskan untuk meminimalkan masalah internal perusahaan sehingga dapat merebut peluang pasar yang lebih baik.

Kuadran 4: merupakan situasi yang sangat tidak menguntungkan karena perusahaan menghadapi berbagai ancaman dan kelemahan internal.

Setelah analisis SWOT dibuat, lalu dibuat matriks SWOT untuk merumuskan alternatif strategi dengan empat set kemungkinan alternatif strategis sebagai berikut:

Strategi SO: Strategi yang memanfaatkan seluruh kekuatan untuk merebut dan memanfaatkan peluang sebesar-besarnya.

StrategiST: Strategi dalam menggunakan kekuatan yang dimiliki perusahaan untuk mengatasi ancaman.

Strategi WO: Strategi ini diterapkan berdasarkan pemanfaatan peluang yang ada dengan cara meminimalkan kelemahan yang ada.

Strategi WT: Strategi ini didasarkan pada kegiatan yang bersifat defensif dan berusaha meminimalkan kelemahan yang ada serta menghindari ancaman. 


\section{HASIL}

Dari data-data yang telah dikumpulkan maka disusun matriks SWOT yang memuat empat set kemungkinan alternatif strategi yang akan dipilih sebagai strategi dalam pengembangan usaha kerajinan limbah hasil perikanan desa Ujung Pandaran, sebagaimana disajikan pada Tabel 1. Hasil identifikasi dan pembobotan terhadap faktor-faktor internal maupun eksternal pada perempuan pesisir pengrajin limbah hasil perikanan disajikan dalam bentuk Matriks IFAS (Internal Factors Analysis Summary) pada Tabel 2 dan matriks EFAS (External Factors Analysis Summary) disajikan pada Tabel 3.

Tabel 1. Matriks SWOT pada pengrajin limbah hasil perikanan desa Ujung Pandaran

\begin{tabular}{|c|c|c|}
\hline IFAS & $\begin{array}{l}\text { STRENGTHS (S) } \\
\text { 1. Waktu luang } \\
\text { 2. Motivasi kuat } \\
\text { 3. Usia potensial } \\
\text { 4. Bahan baku banyak } \\
\text { 5. Bahan baku tahan lama }\end{array}$ & $\begin{array}{l}\qquad \text { WEAKNESS }(\mathbf{W}) \\
\text { 1. Keterbatasan keterampilan } \\
\text { 2. Peralatan minim } \\
\text { 3. Terbatasnya modal } \\
\text { 4. Belum terbentuk kelompok yang } \\
\text { terdaftar di notaris } \\
\text { 5. Pemasaran produk }\end{array}$ \\
\hline $\begin{array}{l}\text { OPPORTUNITIES (O) } \\
\text { 1. Dukungan kebijakan } \\
\text { pemerintah Desa } \\
\text { 2. Program pemberdayaan } \\
\text { perempuan dari Pemerintah } \\
\text { 3. Ikut serta dalam pameran } \\
\text { produk perikanan } \\
\text { 4. Ikut serta dalam pelatihan- } \\
\text { pelatihan } \\
\text { 5. Ujung Pandaran merupakan } \\
\text { DesaWisata } \\
\text { 6. Jaringan pemasaran secara } \\
\text { online dan offline }\end{array}$ & $\begin{array}{l}\text { STRATEGI SO } \\
\text { 1. Meningkatkan Sumber Daya } \\
\text { Manusia dengan memanfaatkan } \\
\text { pelatihan-pelatihan ketrampilan } \\
\text { yang diselenggarakan pihak } \\
\text { Pemerintah maupun swasta. } \\
\text { 2. Memanfaatkan lokasi wisata pantai } \\
\text { Ujung Pandaran yang strategis } \\
\text { untuk memperluas jaringan } \\
\text { pemasaran dengan menggunakan } \\
\text { perkembangan teknologi, baik } \\
\text { secara online (medsos) maupun } \\
\text { offline (ruko atau outlet souvenir) } \\
\text { 3. Bekerjasama dengan Pemerintah } \\
\text { untuk ikut serta dalam pameran } \\
\text { promosi serta melakukan studi } \\
\text { banding ke daerah/sentra produksi } \\
\text { kerajinan limbah hasil perikanan. } \\
\text { 4. Memanfaatkan ajang pameran } \\
\text { untuk bertemu dengan pengrajin } \\
\text { lain sehingga bisa memperluas } \\
\text { peluang pemasaran barang } \\
\text { kerajinan maupun bahan baku. }\end{array}$ & $\begin{array}{l}\text { STRATEGI Wo } \\
\text { 1. Bekerjasama dengan pihak } \\
\text { Pemerintah dan pihak Bank setempat } \\
\text { untuk akses permodalan } \\
\text { 2. Membentuk kelompok pengrajin } \\
\text { limbah hasil perikanan } \\
\text { 3. Mengajukan pendirian usaha kepada } \\
\text { Dinas terkait sehingga mendapatkan } \\
\text { kemudahan dalam pinjaman } \\
\text { 4. Memanfaatkan jaringan pemasaran } \\
\text { baik secara online maupun offline da- } \\
\text { lam memperkenalkan dan memasar- } \\
\text { kan produk. }\end{array}$ \\
\hline $\begin{array}{l}\text { THREATS (T) } \\
\text { 1. Persaingan produk sejenis } \\
\text { 2. Tampilan produk pesaing } \\
\text { lebih menarik } \\
\text { 3. Tuntutan kreatifitas } \\
\text { 4. IPTEK sulit diikuti }\end{array}$ & $\begin{array}{l}\text { STRATEGI ST } \\
\text { 1. Meningkatkan kualitas SDM dan } \\
\text { kualitas hasil kerajinan guna } \\
\text { menghadapi persaingan dari dalam } \\
\text { daerah maupun daerah lain. } \\
\text { 2. Meningkatkan nilai guna produk } \\
\text { kerajinan limbah hasil perikanan } \\
\text { dan kemasan yang unik untuk } \\
\text { menarik perhatian konsumen } \\
\text { 3. Desain produk kerajinan limbah } \\
\text { hasil perikanan dibuat secara unik } \\
\text { dan inovatif } \\
\text { 4. Melakukan promosi untuk menarik } \\
\text { minat masyarakat terhadap produk } \\
\text { kerajinan. }\end{array}$ & $\begin{array}{l}\text { STRATEGI WT } \\
\text { 1. Biaya operasional di tekan sekecil } \\
\text { mungkin untuk mendapatkan harga } \\
\text { yang bersaing. } \\
\text { 2. Meningkatkan tampilan produk } \\
\text { kerajinan limbah hasil perikanan agar } \\
\text { lebih menarik } \\
\text { 3. Meningkatkan mitra penjualan } \\
\text { 4. Memanfaatkan sumber daya manusia } \\
\text { yang berpengetahuan dan terampil } \\
\text { dalam menggunakan teknologi terba- } \\
\text { rukan (modern) serta membangun } \\
\text { jejaring/kemitraan dengan Pemerintah } \\
\text { maupun pihak swasta }\end{array}$ \\
\hline
\end{tabular}


Tabel 2. Matriks IFAS (Internal Factors Analysis Summary) pada perempuan pesisir pengrajin limbah hasil perikanan desa Ujung Pandaran

\begin{tabular}{|c|c|c|c|c|c|}
\hline & FAKTOR-FAKTOR STRATEGI INTERNAL & ВОВОТ & RATING & $\begin{array}{l}\text { BOBOT } x \\
\text { RATING }\end{array}$ & KOMENTAR \\
\hline \multicolumn{6}{|c|}{ KEKUATAN (STRENGTHS) } \\
\hline 1 & Perempuan pesisir mempunyai banyak waktu luang & 0.12 & 4 & 0.48 & $\begin{array}{l}\text { peran utama ibu rumah } \\
\text { tangga }\end{array}$ \\
\hline 2 & $\begin{array}{l}\text { Motivasi kuat untuk membantu perekonomian } \\
\text { keluarga }\end{array}$ & 0.12 & 4 & 0.48 & $\begin{array}{l}\text { mengeringkan ikan asin, } \\
\text { berjualan }\end{array}$ \\
\hline 3 & Usia potensial perempuan pesisir & 0.09 & 3 & 0.27 & kurang dari 50 tahun \\
\hline 4 & Bahan baku banyak tersedia & 0.12 & 4 & 0.48 & tersebar di Desa \\
\hline 5 & Bahan baku tahan lama & 0.12 & 4 & 0.48 & tidak mudah busuk \\
\hline \multicolumn{2}{|r|}{ SUB-TOTAL (I) } & 0.58 & 19 & 2.21 & \\
\hline \multicolumn{6}{|c|}{ KELEMAHAN (WEAKNESS) } \\
\hline 1 & Perempuan pesisir memiliki keterbatasan ketrampilan & 0.09 & 1 & 0.09 & kurang kreatif \\
\hline 2 & $\begin{array}{l}\text { Minimnya peralatan dalam mengolah produk } \\
\text { kerajinan }\end{array}$ & 0.06 & 2 & 0.12 & $\begin{array}{l}\text { kurang kreatif dan } \\
\text { kualitas rendah }\end{array}$ \\
\hline 3 & Terbatasnya modal & 0.09 & 2 & 0.18 & lemahnya akses \\
\hline 4 & Belum terbentuk kelompok yang terdaftar di notaris & 0.09 & 1 & 0.09 & tidak ada kelembagaan \\
\hline 5 & Pemasaran produk masih terbatas & 0.09 & 2 & 0.18 & pemasaran di pameran \\
\hline \multicolumn{2}{|r|}{ SUB-TOTAL (II) } & 0.42 & 8 & 0.67 & \\
\hline \multicolumn{2}{|r|}{ TOTAL (I+II) } & 1.00 & 27 & 2.88 & \\
\hline
\end{tabular}

Tabel 3. Matriks EFAS (Eksternal Factors Analysis Summary) pada perempuan pesisir pengrajin limbah hasil perikanan desa Ujung Pandaran

\begin{tabular}{|c|c|c|c|c|c|}
\hline & FAKTOR-FAKTOR STRATEGI EKSTERNAL & ВОВОт & $\underset{\mathbf{G}}{\text { RATIN }}$ & $\begin{array}{l}\text { BOBOT } x \\
\text { RATING }\end{array}$ & KOMENTAR \\
\hline \multicolumn{6}{|c|}{ PELUANG (OPPORTUNITIES) } \\
\hline 1 & Dukungan kebijakan pemerintah desa & 0.12 & 4 & 0.48 & bantuan peralatan \\
\hline 2 & $\begin{array}{l}\text { Program Pemberdayaan perempuan dari } \\
\text { pemerintah }\end{array}$ & 0.09 & 4 & 0.36 & $\begin{array}{l}\text { pelatihan dan } \\
\text { penyuluhan }\end{array}$ \\
\hline 3 & $\begin{array}{l}\text { Diikutsertakan dalam pameran promosi hasil } \\
\text { perikanan }\end{array}$ & 0.12 & 4 & 0.48 & promosi dan pemasaran \\
\hline 4 & $\begin{array}{l}\text { Keikutsertaan dalam pelatihan-pelatihan bagi } \\
\text { pengrajin }\end{array}$ & 0.12 & 4 & 0.48 & pelatihan \\
\hline 5 & Ujung Pandaran merupakan desa wisata & 0.09 & 3 & 0.27 & pemasaran \\
\hline \multirow[t]{3}{*}{6} & Jaringan pemasaran melalui online dan offline & 0.12 & 4 & 0.48 & promosi dan pemasaran \\
\hline & SUB-TOTAL (I) & 0.67 & 23 & 2.58 & \\
\hline & \multicolumn{5}{|l|}{ ANCAMAN (THREATS) } \\
\hline 1 & $\begin{array}{l}\text { Adanya pesaing produk sejenis dari daerah lain/ } \\
\text { sekitar }\end{array}$ & 0.06 & 1 & 0.06 & dari luar daerah \\
\hline 2 & Belum ada tempat/toko penyalur kerajinan & 0.09 & 1 & 0.09 & tempat penjualan \\
\hline 3 & $\begin{array}{l}\text { Tuntutan konsumen untuk produk yang lebih } \\
\text { kreatif }\end{array}$ & 0.09 & 2 & 0.18 & biaya operasional tinggi \\
\hline \multirow[t]{3}{*}{4} & $\begin{array}{l}\text { Perkembangan IPTEK sulit diikuti perempuan } \\
\text { nelayan }\end{array}$ & 0.09 & 2 & 0.18 & $\begin{array}{l}\text { biaya tinggi dan SDM } \\
\text { rendah }\end{array}$ \\
\hline & SUB-TOTAL (II) & 0.33 & 6 & 0.52 & \\
\hline & TOTAL (I+II) & 1.00 & 29 & 3.09 & \\
\hline
\end{tabular}


Pada Tabel 2 dan Tabel 3 matriks IFAS dan EFAS para perempuan pesisir pengrajin limbah hasil perikanan diketahui memiliki nilai total IFAS sebesar 2,88 sedangkan nilai total EFAS adalah sebesar 3,09. Berdasarkan nilai skor faktor-faktor eksternal dan internal yang telah disusun dalam matriks EFAS dan IFAS tersebut maka dapat dibuat Diagram SWOT untuk menentukan letak kuadran dari strategi yang akan dipilih dengan melakukan perhitungan IFAS sebagai nilai pada sumbu $X$ dan perhitungan EFAS sebagai nilai pada sumbu Y. Nilai skor yang digunakan untuk perhitungan ini merupakan nilai total dari bobot dikalikan dengan ratingnya. Hasil dari perhitungan kekuatan dikurang kelemahan menjadi nilai sumbu $X$, sedangkan hasil dari perhitungan peluang dikurang dengan ancaman merupakan nilai dari sumbu Y. Pembobotan pada faktor internal untuk kekuatan memiliki nilai 2,21 dan untuk kelemahan memiliki nilai 0,67 . Sedangkan pembobotan pada faktor eksternal untuk peluang memiliki nilai 2,58 dan untuk ancaman memiliki nilai 0,52 . Perhitungan dari nilai-nilai tersebut dapat dibuat dalam bentuk tabel yang disajikan pada Tabel 4.

Tabel 4. Perhitungan untuk Sumbu X dan Sumbu $Y$ pada diagram SWOT

\begin{tabular}{clc}
\hline Sumbu & \multicolumn{1}{c}{ Perhitungan } & Hasil \\
\hline$X$ & Kekuatan - Kelemahan & 1,54 \\
& $=2,21-0,67$ & \\
\hline$Y$ & Peluang - Ancaman & 2,06 \\
& $=2,58-0,52$ & \\
\hline
\end{tabular}

Tabel 4 menunjukkan bahwa sumbu $\mathrm{X}$ berada pada nilai 1,54 dan nilai untuk sumbu $Y$ adalah 2,06 . Sehingga dapat dibuat suatu Diagram SWOT untuk menentukan letak kuadrannya seperti ditunjukkan pada Gambar 1.

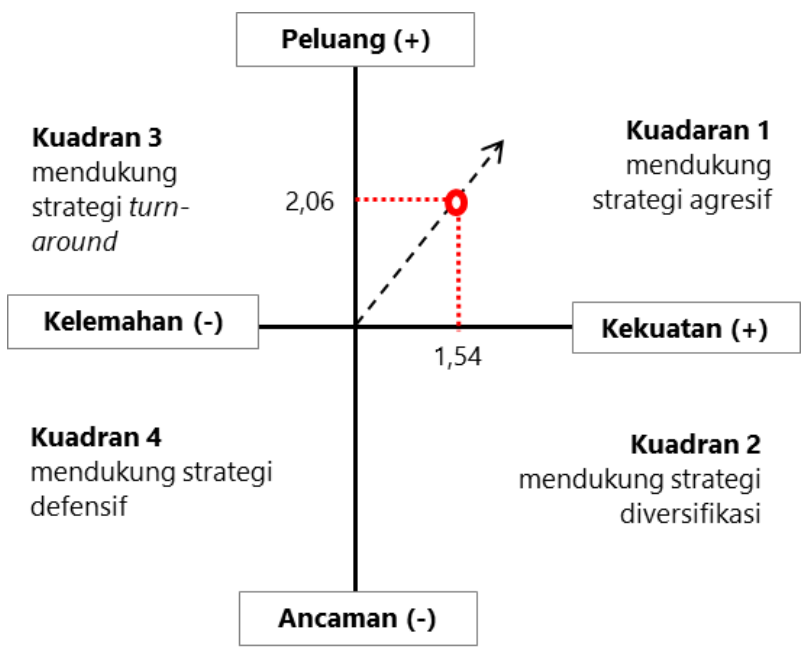

Gambar 1. Diagram SWOT pada pengrajin limbah hasil perikanan desa Ujung Pandaran
Gambar 1 menunjukkan bahwa letak kuadran untuk penentuan strategi dalam meningkatkan kesejahteraan melalui pengembangan usaha pada pengrajin limbah hasil perikanan terletak pada Kuadran 1, yaitu mendukung strategi agresif.

\section{PEMBAHASAN}

\subsection{Analisis Faktor-Faktor Internal}

Lingkungan internal merupakan suatu kondisi yang meliputi faktor-faktor internal sebagai indikator bagi kekuatan maupun kelemahan. Menurut Purnomo dan Zulkieflimansyah (1999) mengungkapkan lingkungan internal adalah lingkungan yang berada di dalam organisasi atau perusahaan tersebut yang secara normal memiliki implikasi langsung dan khusus pada perusahaan yang difokuskan kepada berbagai macam sumberdaya kapabilitas dan kompetensi yang nantinya dapat digunakan untuk membentuk market position tertentu.

Faktor-faktor dalam lingkungan internal ini disajikan pada Tabel 2 yang menunjukkan faktor-faktor internal berupa kekuatan dan kelemahan yang dimiliki oleh perempuan pesisir pengrajin limbah hasil perikanan dalam mengembangkan usahanya di bidang kerajinan limbah. perempuan pesisir desa Ujung Pandaran Kabupaten Kotawaringin Timur harus memaksimalkan kekuatan yang dimiliki dan meminimalkan kelemahan yang ada untuk dapat mengembangan usaha kerajinan limbah hasil perikanan,.

Perempuan pesisir pengrajin limbah hasil perikanan yaitu perempuan pesisir mempunyai beberapa faktor pendukung yang dimiliki, yaitu banyak waktu luang, motivasi yang kuat untuk membantu perekonomian keluarga, usia potensial perempuan pesisir, bahan baku banyak tersedia dan bahan baku tahan lama. Kekuatan internal ini harus dapat lebih ditingkatkan dan dimaksimalkan dengan meminimalkan kelemahankelemahan yang ada berupa terbatasnya keterampilan, minimnya peralatan dalam mengolah produk kerajinan, terbatasnya modal, belum terbentuknya kelompok yang berbadan hukum serta pemasaran produk yang masih terbatas.

Faktor-faktor kekuatan dan kelemahan ini merupakan faktor internal yang dimiliki oleh perempuan pesisir pengrajin limbah hasil perikanan yang harus dapat dimanfaatkan semaksimal mungkin sehingga perempuan pesisir mampu mengembangkan usaha kerajinan limbah hasil perikanan dengan memanfaatkan peluang-peluang yang ada dan mengatasi setiap ancaman yang datang dari luar.

\subsection{Analisis Faktor-Faktor Eksternal}

Lingkungan eksternal merupakan suatu kondisi yang meliputi faktor-faktor eksternal sebagai indikator bagi kekuatan maupun kelemahan yang dimiliki perempuan pesisir dalam melakukan kerajinan limbah hasil 
perikanan. Purnomo dan Zulkieflimansyah (1999) mengungkapkan lingkungan eksternal adalah lingkungan perusahaan atau organisasi yang menyusun faktor-faktor yang memiliki ruang lingkup luas dan faktor-faktor tersebut pada dasarnya diluar dan terlepas dari operasi perusahaan atau organisasi. Faktor-faktor tersebut diantaranya adalah faktor ekonomi, sosial, politik dan hukum, teknologi serta demografi. Faktor-faktor dalam lingkungan eksternal ini disajikan pada Tabel 4. yang menunjukkan faktor-faktor eksternal berupa peluang maupun ancaman yang dihadapi oleh perempuan pesisir pengrajin limbah hasil perikanan dalam mengembangkan usaha kerajinannya.

Perempuan pesisir pengrajin limbah ahsil perikanan memiliki beberapa peluang, yaitu adanya dukungan kebijakan dari Pemerintah dengan program-program pemberdayaan yang dilaksanakan, diikusertakan dalam pameran promosi hasil perikanan, keikutsertaan dalam pelatihan-pelatihan bagi pengrajin limbah hasil perikanan, memanfaatkan tempat-tempat wisata di Desa Ujung Pandaran serta memperluas jaringan pemasaran sehingga pemasaran produk tidak hanya dilakukan secara offline tetapi juga dapat dilakukan secara online.

Pesaing produk sejenis dari daerah lain/sekitar, belum adanya tempat atau toko penyalur kerajinan, tuntutan konsumen untuk produk yang lebih kreatif, serta perkembangan IPTEK yang sulit untuk diikuti perempuan nelayan merupakan faktor-faktor yang menjadi kelemahan yang harus diatasi oleh perempuan pesisir pengrajin limbah hasil perikanan dengan memanfaatkan peluang-peluang yang ada.

\subsection{Strategi Peningkatan Kesejahteraan Ekonomi Masyarakat Pesisir}

Peran perempuan pesisir dapat dikembangkan untuk meningkatkan kesejahteraan ekonomi masyarakat. Perempuan pesisir dapat meningkatkan sumberdaya manusia dan keterampilan dalam mengolah produkproduk kerajinan limbah hasil perikanan sesuai dengan tuntutan pasar serta menghindari ancaman-ancaman yang dapat menghambat peningkatan kesejahteraan ekonomi masyarakat pesisir.

Strategi yang dihasilkan berdasarkan Analisis SWOT disajikan pada Tabel 2 yang menunjukkan beberapa alternatif strategi yang dapat diterapkan dalam peningkatan kesejahteraan ekonomi masyarakat pesisir di desa Ujung Pandaran melalui pemberdayaan perempuan dengan memanfaatkan limbah hasil perikanan. Matriks SWOT memuat empat set kemungkinan alternatif strategi yang akan dipilih sebagai strategi dalam meningkatkan kesejahteraan ekonomi masyarakat pesisir.

Dari empat set alternatif tersebut di atas, strategi yang dapat diterapkan sesuai dengan kuadran pada Diagram SWOT disajikan pada Gambar 1. terletak pada Kuadran 1, yaitu mendukung strategi agresif. Kuadran 1 ini merupakan situasi yang sangat menguntungkan, dimana perusahaan memiliki peluang (Opportunities) dan kekuatan (Strenghts) sehingga dapat memanfaatkan peluang yang ada. Strategi yang harus diterapkan dalam kondisi ini adalah mendukung kebijakan pertumbuhan yang agresif (growth oriented strategy).

Strategi SO dapat diterapkan untuk meningkatkan kesejahteraan ekonomi masyarakat pesisir berdasarkan hasil dari analisis SWOT. Strategi SO merupakan strategi yang digunakan karena memiliki peluang dan kekuatan yang dapat dimanfaatkan dalam pengembangan usahanya ke masa yang akan datang sehingga strategi ini dapat dikategorikan sebagai strategi yang menggunakan kekuatan internal untuk memanfaatkan peluang-peluang eksternal yang ada.

Perempuan pesisir pengrajin limbah hasil perikanan dapat memaksimalkan kekuatan yang ada dengan memanfaatkan waktu luang dari peran intinya sebagai Ibu Rumah Tangga serta bahan baku yang banyak tersedia di daerah tersebut untuk melakukan kerajinan limbah hasil perikanan. Selain itu adanya motivasi yang kuat untuk membantu perekonomian keluarga serta peran dukungan dari pihak pemerintah dalam mengembangkan pemberdayaan masyarakat, dapat dimanfaatkan dengan baik bagi perempuan pesisir pengrajin limbah hasil perikanan untuk mengikuti pelatihan-pelatihan yang bersifat softskill untuk meningkatkan kreatifitas produk yang dihasilkan.

Perempuan pesisir pengrajin limbah hasil perikanan juga dapat memanfaatkan lokasi wisata pantai Ujung Pandaran, dengan orientasi konsumen yang merupakan wisatawan dari luar daerah dengan menambah tempat pendistribusian produk kerajinan limbah hasil perikanan seperti ruko-ruko atau outlet souvenir dengan menawarkan produk kerajinan yang mencirikan daerah tersebut. Selain itu, untuk memperluas jaringan pemasaran secara online perempuan pesisir dapat menggunakan perkembangan teknologi baik melalui media sosial maupun penjualan online.

Kelompok perempuan pesisir pengrajin limbah hasil perikanan juga dapat memanfaatkan ajang pameran dan promosi yang bekerjasama dengan Pemerintah untuk memperkenalkan produk-produk yang dihasilkan oleh perempuan pesisir pengrajin limbah hasil perikanan ke pasaran baik di tingkat lokal (dalam daerah) maupun nasional (luar daerah). Kesejahteraan ekonomi masyarakat sekitar dapat ditingkatkan dengan menerapkan strategi tersebut untuk mencapai hasil akhir yang akan memberikan keuntungan pada semua pihak, terutama bagi perempuan pesisir pengrajin limbah hasil perikanan.

\section{KESIMPULAN DAN SARAN}

Analisis SWOT menunjukkan beberapa alternatif strategi yang dapat diterapkan dalam meningkatkan kesejahteraan ekonomi masyarakat pesisir melalui 
pemberdayaan perempuan. Strategi SO dapat memaksimalkan kekuatan dalam merebut dan memanfaatkan peluang yang ada yaitu meningkatkan sumberdaya manusia dengan memanfaatkan pelatihanpelatihan keterampilan yang diselenggarakan pihak Pemerintah maupun Swasta, memanfaatkan lokasi wisata pantai Ujung Pandaran yang strategis untuk memperluas jaringan pemasaran dengan menggunakan perkembangan teknologi, baik secara online (media sosial) maupun offline (ruko atau outlet souvenir), bekerjasama dengan Pemerintah untuk ikut serta dalam pameran promosi serta melakukan studi banding ke daerah atau sentra produksi kerajinan limbah hasil perikanan dan memanfaatkan ajang pameran untuk bertemu dengan pengrajin lain sehingga bisa memperluas peluang pemasaran barang kerajinan maupun bahan baku.

Berdasarkan kajian tersebut disarankan beberapa hal sebagai berikut:

1. Memudahkan perempuan pesisir memasarkan produk kerajinannya. Tempat khusus seperti toko atau outlet souvenir yang merupakan tujuan utama wisatawan perlu dibangun di lokasi wisata pantai Ujung Pandaran, selain itu juga tetap melakukan promosi dengan memanfaatkan teknologi secara online (media sosial).

2. Membentuk kelembagaan atau kelompok perempuan pesisir pengrajin limbah hasil perikanan, sehingga mempermudah dalam melakukan pinjaman ke pihak bank maupun kerjasama promosi dan pelatihanpelatihan bersama dinas terkait.

3. Pemerintah daerah melalui Dinas Kelautan dan Perikanan hendaknya mampu memberdayakan perempuan pesisir dengan memperhatikan apa yang menjadi kebutuhan sehingga tepat sasaran. Perempuan pesisir pengrajin limbah hasil perikanan perlu diberikan pelatihan kreatifitas maupun pelatihan menggunkan teknologi terbarukan (modern) serta pendampingan secara rutin kepada sehingga dapat meningkatkan kesejahteraan ekonomi masyarakat sekitar.

\section{DAFTAR PUSTAKA}

Badan Pusat Statistik. 2000. Indikator sosial ekonomi indonesia. Badan Pusat Statistik Indonesia. Jakarta

Duradin, D., 2017. Kebijakan Pemerintah di Bidang Perikanan untuk Pelestarian Lingkungan Hidup dan Kesejahteraan Nelayan. Syntax Literate; Jurnal IImiah Indonesia, 2(12), 22-34.

Handajani, H., Relawati, R. and Handayanto, E., 2016. Peran Gender dalam Keluarga Nelayan Tradisional dan Implikasinya Pada Model Pemberdayaan Perempuan di Kawasan Pesisir Malang Selatan. Jurnal Perempuan dan Anak, 1(1), 1-21.
Heriyanto, M., Farida, L. and Andini, F.K., 2017. Perempuan Bekerja dalam Meningkatkan Pendapatan Keluarga di Wilayah Pesisir. Jurnal Aplikasi Bisnis, 8(1), 63-68.

Hilyana, S., Amir, S., Marzuki, M. and Damayanti, A.A., 2019. Pemberdayaan Wanita Pesisir Melalui Olahan Pangan Berbasis Mangrove di Desa Paremas Kabupaten Lombok Timur. Prosiding PEPADU, 1(1), 416-424.

Imaniar, D., 2017. Pemberdayaan Masyarakat Pesisir (Perempuan Nelayan) Melalui Pemanfaatan Pengolahan Limbah Laut dan Cangkang Kerang. Jurnal Humaniora, 14(2), 62-66.

Karina, D., Nuraini, T.A. and Indriawati, P. 2018. Peran Perempuan dalam Meningkatkan Pendapatan Ekonomi Rumah Tangga Nelayan di Kelurahan Manggar Baru Balikpapan. Jurnal Edueco, 1(2), 26-36.

Kementerian Pemberdayaan Perempuan dan Perlindungan Anak Republik Indonesia. 2010. Online: https://www.kemenpppa.go.id/lib/uploads/list/d7baapedoman-teknis-pprg-daerah diakses pada tanggal 03 April 2019.

Koralagama, D., Gupta, J. and Pouw, N., 2017. Inclusive development from a gender perspective in small scale fisheries. Current Opinion in Environmental Sustainability, 24, 1-6.

Menggala, S.R. 2016. Kemiskinan Pada Masyarakat Nelayan di Cilincing. The Indonesian Journal of Public Administration (IJPA), 2(1), 59-68.

Nurlaili, N. and Muhartono, R. 2017. Peran Perempuan Nelayan dalam Usaha Perikanan Tangkap dan Peningkatan Ekonomi Rumah Tangga Pesisir Teluk Jakarta.Jurnal Sosial Ekonomi Kelautan Dan Perikanan, 12(2), 203-212.

Pemerintah Provinsi Kalimantan Tengah. 2018. Satu Data Kalteng. Online: https://satudata.kalteng.go.id/ satudata/tabel/index/ di akses pada tanggal 03 April 2019

Program Pascasarjana Universitas Palangka Raya. 2017. Panduan Penulisan Usulan Penelitian dan Tesis. Universitas Palangka Raya, Palangka Raya.

Purnomo, H.S. and Zulkieflimansyah, M.S.S.K.P., 1999. Manajemen Strategi. Lembaga Penerbit Fakultas Ekonomi Universitas Indonesia.

Putri, D.Y. and Eriyanti, F., 2019. Peran Istri Nelayan Tradisional dalam Meningkatkan Pendapatan Keluarga Melalui Kewirausahaan di Kecamatan Koto Tangah Kota Padang. Ranah Research: Journal of Multidisciplinary Research and Development, 1(3), 473 $-482$.

Rahim, A., 2018. The Empowerment Strategy of The Traditional Fisherman's Wives in The Coastal Area of Barru Regency, South Sulawesi. Journal of Socioeconomics and Development, 1(1), 1-6.

Rangkuti, F. 2017. Analisis SWOT Teknik Membedah Kasus Bisnis Cara Perhitungan Bobot. Rating, dan OCAI. PT Gramedia Pustaka Utama, Jakarta. 
Ropiah, S., Susanto, T. and Ramdhani, M. 2018. Analisis Strategi Komunikasi Pemasaran De Box Cafe dalam Menarik Minat Konsumen. Jurnal Politikom Indonesiana, 3(2), 231-239.

Rostiyati, A., 2018. Peran Ganda Perempuan Nelayan di Desa Muara Gading Mas Lampung Timur. Patanjala, 10(2), 187-202.

Sugiyono, D., 2010. Metode penelitian kuantitatif dan kualitatif. Bandung: CV Alfabeta.
Widodo, S., Bustamam, H., and Soengkono. 2011. Model Pemberdayaan Ekonomi Perempuan Keluarga Nelayan Miskin Melalui Penerapan Teknologi Tepat Guna Terpadu (Studi Keluarga Nelayan Di Kecamatan Pondok Kelapa Kabupaten Bengkulu Utara). Jurnal Ekonomi dan Bisnis Airlangga (JEBA)| Journal of Economics and Business Airlangga, 21(1), 14-24. 